\title{
Osmoregulatory, metabolic, and nutritional condition of summer-run male Chinook salmon in relation to their fate and migratory behavior in a regulated river
}

\author{
Caleb T. Hasler ${ }^{1, *}$, Michael R. Donaldson ${ }^{2}$, Rana P. B. Sunder ${ }^{1}$, Esther Guimond ${ }^{3}$, \\ David A. Patterson ${ }^{4}$, Brent Mossop ${ }^{5}$, Scott G. Hinch ${ }^{2}$, Steven J. Cooke ${ }^{1}$ \\ ${ }^{1}$ Fish Ecology and Conservation Physiology Laboratory, Department of Biology and Institute of Environmental Science, \\ Carleton University, 1125 Colonel By Drive, Ottawa, Ontario K1S 5B6, Canada \\ ${ }^{2}$ Centre for Applied Conservation Research, Department of Forest Sciences, University of British Columbia, 2424 Main Mall, \\ Vancouver, British Columbia V6T 1Z4, Canada \\ ${ }^{3}$ Guimond Environmental Consulting, 473 Leighton Ave., Courtenay, British Columbia V9N 2Z5, Canada \\ ${ }^{4}$ Fisheries and Oceans Canada, Science Branch, Pacific Region, Cooperative Resource Management Institute, \\ School of Resource and Environmental Management, Simon Fraser University, Burnaby, British Columbia V5A 1S6, Canada \\ ${ }^{5}$ BC Hydro, 6911 Southpoint Drive, Burnaby, British Columbia V3N 4X8, Canada
}

\begin{abstract}
We studied the migratory success of male summer-run Chinook salmon Oncorhynchus tshawytscha in the Puntledge River on Canada's Vancouver Island over a 3 yr period using biotelemetry and non-lethal physiological biopsy. Principal component analysis was used to group co-varying physiological variables prior to comparing fish with different migratory behaviors (e.g. migration rate, holding times) and fate (migration and spawning success). Fish with low levels of endogenous energy stores (total protein, cholesterol, and triglycerides) and dietary minerals (calcium, magnesium, and phosphorus) at the time of sampling were found to subsequently ascend the most upstream natural barrier (Nib Falls) significantly faster than fish with higher levels. Fate was weakly associated with several physiological characteristics; successful migrants had significantly higher hematocrit values and significantly lower plasma K+ relative to failed migrants, suggesting that fish condition at river entry can influence subsequent behavior. Our results indicate that physiological and nutritional condition can influence adult migrating male summer-run Chinook salmon, but we did not find a physiological profile that could explain all behaviors and fates observed. This study represents one of the first to apply conservation physiology tools to study an imperiled river fish population.
\end{abstract}

KEY WORDS: Pacific salmon · Biotelemetry · Physiology · Spawning migration · Anthropogenic effects

\section{INTRODUCTION}

Hydropower infrastructure (e.g. dams, generating stations) and operations can interrupt a river's natural flow regime, fish habitat, and system connectivity, and thus has the potential to negatively influence the upstream migration of fish, particularly anadromous fish such as salmonids that must travel upriver to natal spawning grounds (Poff et al. 1997, Enders et al. 2009). Recent studies have demonstrated delays (Thorstad et al. 2003, Keefer et al. 2004, 2008, Pon et al. 2009a) or failure of mature adult salmon to reach spawning grounds (e.g. Gowans et al. 2003, Thorstad et al. 2003) and higher energetic costs for salmonids exposed to 
variable water flows (Murchie \& Smokorowski 2004, Tiffan et al. 2010) in regulated rivers. Although numerous studies have measured fish behaviors in association with hydropower operations and infrastructure, only Pon et al. (2009a,b) and Roscoe et al. (2011) have assessed the physiological status of free-swimming fish relative to their encountering a barrier, their ability to pass the structure, and post-passage survival. However, little is known about how physiological condition influences the behavior and survival of fish passing through multiple obstructions and barriers en route to spawning areas.

It is likely that the physiological status of maturing adults at the time of entry into a hydropower-impacted river influences migratory behavior, as the freshwater migrations of spawning salmon, regardless of the degree to which the river is impacted by hydropower, are physiologically challenging and energetically demanding (Ueda \& Yamauchi 1995, Hinch et al. 2006). Indeed, recent research on the Fraser River in British Columbia, Canada, has determined that physiological condition of individual fish during the coastal approach is correlated with behavior and fate at time of river entry (Cooke et al. 2008a, Crossin et al. 2009a), as is condition at time of capture in the river with behavior and survival in more upstream reaches (Young et al. 2006, Donaldson et al. 2010, Mathes et al. 2010). These studies are possible through the use of a non-lethal biopsy approach whereby small blood and gill samples are obtained from fish that are subsequently outfitted with a telemetry tag and released (Cooke et al. 2005, 2006a, 2008b, Miller et al. 2011). Although this correlative approach between physiological condition and subsequent behavior and fate does not reveal causal links (Cooke \& O'Connor 2010), it can identify factors that may be contributing to migration failure or aberrant behaviors. Thus, understanding variation in fish condition and physiology can help us understand the impact of hydropower infrastructure and operations and better inform appropriate mitigation and compensation strategies (Caudill et al. 2007, Hasler et al. 2009).

The aim of the present study was to understand the linkages between nutritional status, physiological stress, and migratory behaviors and fates of adult salmon which must pass multiple obstructions en route to spawning areas. The study animals were male summer-run Chinook salmon Oncorhynchus tshawytscha (SCS) which ascend the Puntledge River in British Columbia, Canada. Very little is known on the behavioral physiology of migration of SCS; moreover, this particular stock is imperiled (Hirst 1991), and recent management actions have focused on facilitating upstream migration. Specifically, the stock has decreased from 4500 individuals historically, to fewer than 1600 returning adults (D. Miller pers. comm.). Thus our results have the potential to facilitate recovery and conservation by indicating possible biological mechanisms for the population decline. Previous studies of this kind, although few, have tended to focus on larger, lower gradient systems with few obstructions (e.g. Fraser River, Cooke et al. 2008a,b, Crossin et al. 2009b; Thompson River, Young et al. 2006) and have focused nearly exclusively on sockeye salmon as models. We used radio-telemetry in tandem with blood and gill sampling obtained for physiological analysis (Cooke et al. 2005) to test 2 broad hypotheses: (1) physiological status, energy use, and osmoregulatory status will differentiate migratory behaviors (i.e. time holding, time to ascend) of fish at 'key barriers' to upstream movement, and (2) SCS that successfully reach spawning grounds will be characterized by low levels of physiological stress, will be in good nutritional condition, and will be in a state of high osmoregulatory preparedness relative to fish that do not reach spawning grounds.

\section{MATERIALS AND METHODS}

SCS and the Puntledge River. The Puntledge River SCS have been experiencing steep declines in returning adults (Hirst 1991, Department of Fisheries and Oceans [DFO] Puntledge Hatchery unpubl. data). The decrease in returning adults is occurring despite numerous restoration and enhancement efforts by government agencies and the hydropower utility, including construction of fish ladders at Comox Dam and the diversion dam, modifications to natural obstructions, flow manipulations to facilitate upstream movement of returning salmon, stocking programs (thousands of juvenile fish are released from below the diversion dam at River $\mathrm{km}[\mathrm{Rkm}]$ 13.3, and from the release site at Rkm 6.4; Fig. 1), and other habitat enhancement initiatives (i.e. addition of spawning gravel, side channels for refuge use by juveniles; Hirst 1991, D. Miller pers. comm.).

The Puntledge River is $16.9 \mathrm{Rkm}$ and has been impacted by hydropower operations and infrastructure. The main impact is that there are multiple artificial and natural barriers to fish migration (Fig. 1). At Rkm 13.3, a portion of the river's discharge is diverted by a diversion dam into a penstock, and subsequently re-joins the river at Rkm 6.8 (Fig. 1). At the output of the penstock there is a pool (Powerhouse Pool) that SCS must pass before entering the diversion reach (Reach $\mathrm{C}$ in Fig. 1). Reduced discharge in the diversion reach may affect the migration of SCS. In particular, discharge at 2 major natural barriers to fish migration (Stotan Falls and Nib Falls; Fig. 1) seems to delay 


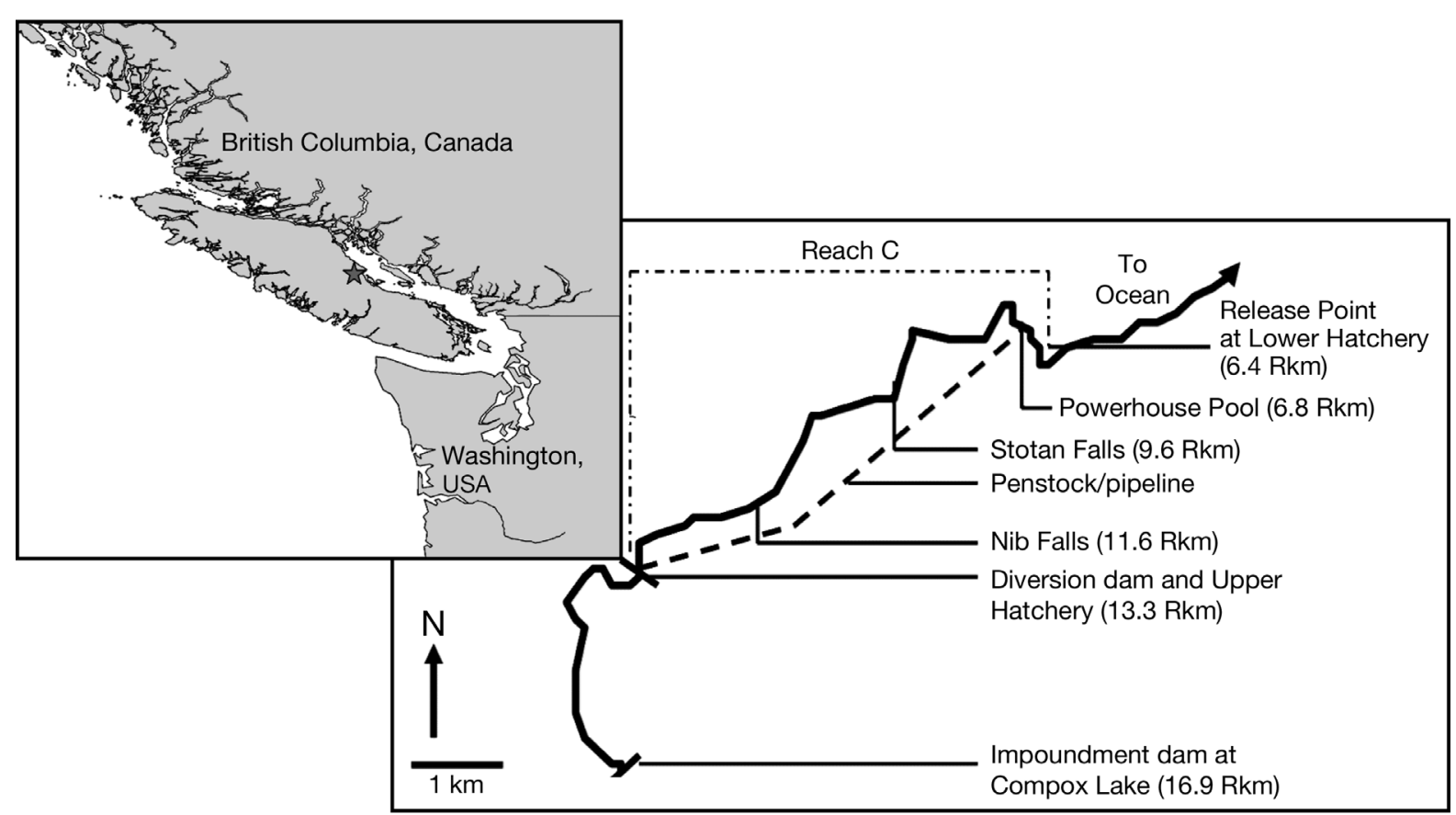

Fig. 1. Location of the study area in the Pacific Northwest and a map of the key areas in the study area with the distance from the estuary in parentheses. Rkm: River km

migration. Both of these barriers each have 3 sets of blasted-rock fish stairs. Once fish have migrated above Nib Falls, they must navigate through a fishway (pool and weir type) at the diversion dam in order to access the headwaters and historic spawning gravel beds (Rkm 16.9 upstream of the river mouth). SCS have been observed spawning from approximately Rkm 9.6 to 16.9 upstream and thus we classified fish as spawners once they passed the $9.6 \mathrm{Rkm}$ mark and exhibited further behaviors that indicated that they were alive. Fish were tagged and released at the lower hatchery (Rkm 6.5) and were tracked throughout the study reach by observers walking the shoreline of the river and using fixed stations near 3 locations that are known physical or behavioral barriers: the Powerhouse Pool, Stotan Falls, and Nib Falls. During tagging days, river temperature and discharge in the diversion reach ranged from 15 to $17^{\circ} \mathrm{C}$ and 5.9 to $6.8 \mathrm{~m}^{3} \mathrm{~s}^{-1}$. River temperature throughout the migration period ranged from 11 to $24^{\circ} \mathrm{C}$ and discharge ranged from 4 to $>16 \mathrm{~m}^{3} \mathrm{~s}^{-1}$.

Study animals, tagging, and biosampling procedures, assays, and tracking. Between 30 June and 20 July 2007 and 2008, and between 2 and 26 June 2009, male adult SCS (females were not permitted to be used in the study because of the need to use them in the brood stock program) were diverted into raceways at the Lower Puntledge River Fish Hatchery (DFO; Fig. 1) for physiological sampling and transmitter implantation (2007: 21 fish; total length [TL] = $691 \pm$ $79 \mathrm{~mm}$; 2008: $13 \mathrm{fish}, \mathrm{TL}=663 \pm 59 \mathrm{~mm}$; 2009: 24 fish, $\mathrm{TL}=645 \pm 62 \mathrm{~mm}$ ). Upon capture from the hatchery raceway using a 'herding' and dip net method, all fish were sampled for blood and gill tissue (see biopsy methods in Cooke et al. 2005). Briefly, fish were placed supine in a V-shaped trough filled with water, and $1.5 \mathrm{ml}$ of blood was drawn from the caudal vasculature using a $3 \mathrm{ml}$ Vacutainer (with lithium heparin; Becton Dickson) with a 1.5 in $(3.8 \mathrm{~cm}) 21$ gauge needle. Less than $4 \mathrm{~mm}$ of tips from 6 to 8 gill filaments from the first gill arch were removed (McCormick 1993) and immediately frozen in liquid nitrogen. Blood was immediately placed in a water-ice slurry prior to centrifuging at $10000 \times g$ (Compact II Centrifuge; Clay Adams). Plasma was aliquoted into vials and frozen in liquid nitrogen prior to transferring samples to a $-80^{\circ} \mathrm{C}$ freezer.

Plasma was analyzed by IDEXX Laboratory (Markham, Ontario, Canada) for total protein, aspartate transaminase (AST), cholesterol, triglycerides, glucose, sodium, potassium, chloride, calcium, phosphorus, and magnesium using a Roche-Hitachi Analyzer (Wagner \& Congleton 2004). Variables were chosen based on previous work (see Cooke et al. 2006b, Pon et al. 2009a,b).

Once fish had been sampled for blood and measured for TL $(\mathrm{mm})$, a radio transmitter was gastrically inserted into each fish with the antenna protruding 
from the oral cavity (MCFT-3A, Lotek Engineering). Fish were held for up to $60 \mathrm{~min}$ in a cage $(1.2 \times 2.0 \times$ $0.6 \mathrm{~m}$, which was a gated off portion of the fishway entrance to the hatchery) to facilitate recovery and then released directly upstream of the Lower Hatchery fence. Fish were manually tracked from shore twice a day using a telemetry receiver (SRX-600, Lotek Engineering) and a 3-pronged Yagi antenna. Fish locations were determined using the successive gain reduction technique (Cooke et al. 2004). The river is narrow and there is a minimum number of possible locations fish can inhabit, so transmitter locations are easily found with a high degree of accuracy. Fish were tracked from 30 June to 5 November 2007, 30 June to 7 November 2008, and 2 June to 6 November 2009. Tracking occurred twice a day up to 5 August, and then weekly until the post-spawn die-off (early November).

Data analysis. Five key metrics of migratory behavior in the Puntledge River were calculated by counting the number of day: (1) fish were located at the Powerhouse Pool, (2) fish took to migrate between the Powerhouse Pool and Stotan Falls, (3) between arriving at and ascending over Stotan Falls, (4) fish took to migrate between Stotan Falls and Nib Falls, and (5) between arriving at and ascending over Nib Falls. These milestones were used because they are key holding areas and sites of concern to the local stakeholders (Taylor \& Guimond 2004). Furthermore, to avoid autocorrelation, relative times to ascend were used and were not continuous. Yearly differences between each of the migratory behaviors were analyzed using Kruskal-Wallis non-parametric analysis of variance (ANOVA), and correlations between each of the migratory behaviors were done to assess the independence of each variable.

To test for yearly differences between the blood variables, the mean of each blood variable was compared across years using Kruskal-Wallis non-parametric ANOVAs because the assumptions of a 1-way ANOVA were not met. A principal component analysis (PCA) with a Varimax factor rotation (an orthogonal transformation of factors with eigenvalues $\geq 1$ included) was used to simplify the predictor variables (blood variables) by partitioning autocorrelated variables together (Wagner \& Congleton 2004). The PCA grouped the correlated blood variables together and created uncorrelated factors that were subsequently used for analyses. A log transformation was used when blood variables were not normally distributed prior to the PCA to meet the assumption of normalcy. Within each factor, blood variables were considered to contribute to the factor if the rotated factor loading was $\geq 0.5$. This characterized the factors by only the blood variables that contributed the most to the variance explained for each factor. Rotated factors were then linearly regressed with each of the 5 metrics of migratory behavior (see 1 to 5 above). In addition, rotated factors were logistically regressed with whether a fish held (minimum of $1 \mathrm{~d}$ ) at the Powerhouse Pool, ascended Stotan Falls, or ascended Nib Falls, and with fate (spawner: carcass found above Stotan Falls and movement occurred near time of spawning; prespawn mortality: no movement prior to spawning period and/or tag found before spawning period; or fallback: fish moved downstream of the Lower Hatchery main fence). Prespawn mortality and fallback were grouped in the logistical analysis. All statistical analysis was done using JMP 7.0.2 (SAS Institute), and significance was tested at $\alpha=0.01$ (Bonferroni correction 5 behaviors) for yearly differences in migratory behavior, at $\alpha=0.004$ (Bonferroni correction; 12 blood variables) for yearly differences in blood variables, and at $\alpha=0.013$ (Bonferroni correction; 4 rotated factors) for comparisons of blood variables and migratory behavior and fate.

\section{RESULTS}

\section{Migratory behavior and fates of SCS}

There were few correlations ( 3 of 13) between the different migratory behavior variables used in the analysis (days located at the Powerhouse Pool and days to Stotan Falls, $r=0.67, \mathrm{p}<0.001$; days to ascend Stotan Falls and days to Nib Falls, $r=0.37, p=0.017$; and days to migrate between Stotan Falls and Nib Falls and days to ascend Nib Falls, $r=0.53, p=0.001$ ).

Migratory behaviors of the tagged Puntledge River SCS did not vary between years (Table 1). Of the 58 tagged fish, $45 \%$ held at the Powerhouse Pool (proportions do not include the fish that held for $0 \mathrm{~d}$ or spent $0 \mathrm{~d}$ traveling between sites; Table 1 ). There was no effect of year on mean days held at the Powerhouse Pool (Kruskal-Wallis; $\chi^{2}=5.67 ; \mathrm{p}=0.06$; Table 1). Of the tagged fish, $91 \%$ (53 of 58) moved upstream to Stotan Falls. There was no significant year effect (Kruskal-Wallis; $\chi^{2}=8.12 ; \mathrm{p}=0.02$; Table 1 ). The ascending rate (i.e. the number of fish that passed Stotan Falls) was $74 \%$ (39 of 53). Fish ascended Stotan Falls on average in $8 \mathrm{~d}$ (range $=1-47$; Table 1 ), with no significant year effect (Kruskal-Wallis; $\chi^{2}=3.76 ; \mathrm{p}=$ 0.15 ; Table 1). All of the fish $(\mathrm{n}=39)$ that ascended Stotan Falls reached Nib Falls, and the mean length of time to reach the barrier was $2 \mathrm{~d}$ (range 0-20 d) once the fish passed Stotan Falls; again, there was no significant year effect (Kruskal-Wallis; $\chi^{2}=4.80 ; \mathrm{p}=0.09$ ). The ascending rate at Nib Falls was $85 \%$, as 33 of 39 fish ascended the falls in $3 \mathrm{~d}$ on average (range $0-11$; Table 1) with no significant year effect (Kruskal-Wallis; $\chi^{2}=2.66 ; \mathrm{p}=0.26$ ). 
Table 1. Oncorhynchus tshawytscha. Summary of the migratory behavior metrics in the upstream migration of 58 radio-tracked summer-run Chinook salmon in the Puntledge River, British Columbia. '0 d' at the Powerhouse Pool (PHP) indicates that some tagged fish did not hold at the site for more than $1 \mathrm{~d}$. 'Days' are mean values (range in parentheses); no.: no. of salmon. There were no statistically significant differences between years and the 5 migratory behavior metrics. SF: Stotan Falls, NF: Nib Falls

\begin{tabular}{|cccccccccccc|}
\hline Year & $\begin{array}{c}\text { No. } \\
\text { tagged }\end{array}$ & $\begin{array}{c}\text { No. held } \\
\text { at PHP }\end{array}$ & $\begin{array}{c}\text { Days held } \\
\text { at PHP }\end{array}$ & $\begin{array}{c}\text { No. to } \\
\text { SF }\end{array}$ & $\begin{array}{c}\text { Days from } \\
\text { PHP to SF }\end{array}$ & $\begin{array}{c}\text { No. } \\
\text { passing SF }\end{array}$ & $\begin{array}{c}\text { Days to } \\
\text { ascend SF }\end{array}$ & $\begin{array}{c}\text { No. to Days from } \\
\text { NF }\end{array}$ & $\begin{array}{c}\text { No. } \\
\text { SF to NF }\end{array}$ & $\begin{array}{c}\text { Days to } \\
\text { passing NF ascend NF }\end{array}$ \\
\hline 2007 & 21 & 8 & $2(0-17)$ & 21 & $8(2-22)$ & 14 & $13(2-47)$ & 14 & $3(0-20)$ & 11 & $3(1-11)$ \\
2008 & 13 & 4 & $5(0-41)$ & 13 & $5(1-12)$ & 7 & $7(1-22)$ & 7 & $1(0-3)$ & 5 & $4(2-10)$ \\
2009 & 24 & 14 & $7(0-25)$ & 19 & $15(2-29)$ & 18 & $5(1-19)$ & 18 & $1(0-5)$ & 17 & $2(0-5)$ \\
Sum: & 58 & 26 & Mean: $4(0-41)$ & 53 & $11(1-29)$ & 39 & $8(1-47)$ & 39 & $2(0-20)$ & 33 & $3(0-11)$ \\
\hline
\end{tabular}

In total, 38 fish were classified as being possible spawners (i.e. successfully ascended Stotan Falls and did not fall back or were not found dead prior to the spawning time); 8 were classified as pre-spawn mortalities, and 12 as fallbacks (Table 2). The spawning fate of the tracked fish did not differ between years (Pearson; $\left.\chi^{2}=3.767 ; \mathrm{p}=0.439\right)$ and between dates tagged (Pearson; $\chi^{2}=10.725 ; \mathrm{p}=0.708$ ).

\section{Blood variables}

Yearly means for blood variables were similar across years for all but one variable (sodium; Table 3). In 2008, sampled SCS had significantly higher values of sodium $\left(\right.$ mean $\left.\pm \mathrm{SD}=171 \pm 7 \mathrm{mmol} \mathrm{l}^{-1}\right)$ than in $2007(164 \pm$ $\left.5 \mathrm{mmol} \mathrm{l}^{-1}\right)$ and $2009\left(161 \pm 7 \mathrm{mmol}^{-1}\right.$; Table 3$)$.

A PCA and subsequent orthogonal factor rotation of the loadings was found to explain $73.2 \%$ of the variance in blood variables (Table 4). Rotated factor 1 represented endogenous energy stores and dietary minerals. It was characterized by high positive factor loadings for calcium, total protein, magnesium, cholesterol, triglycerides, and phosphorus (Table 4), and accounted for $33.4 \%$ of the variance. Rotated factor 2 was characterized by high positive factor loadings for chloride and sodium, and high negative factor loadings for AST and potassium (Table 4), mainly representing osmoregulatory preparedness (with the ex-

Table 2. Oncorhynchus tshawytscha. Fate of 58 radio-tracked summer-run Chinook salmon in the Puntledge River and percentage of total sample size (in parentheses). There were no statistical differences between year and fate

\begin{tabular}{|cccc|}
\hline Year & $\begin{array}{c}\text { Possible } \\
\text { spawners }\end{array}$ & $\begin{array}{c}\text { Pre-spawn } \\
\text { mortalities }\end{array}$ & Fallbacks \\
\hline 2007 & $14(67)$ & $4(19)$ & $3(14)$ \\
2008 & $7(54)$ & $1(8)$ & $5(38)$ \\
2009 & $17(70)$ & $3(13)$ & $4(17)$ \\
Sum & $38(66)$ & $8(14)$ & $12(20)$ \\
\hline
\end{tabular}

Table 3. Oncorhynchus tshawytscha. Means $( \pm \mathrm{SD})$ for blood physiology variables included in the datasets for summer-run Chinook salmon from the Puntledge River. Bold denotes statistical differences between years (Kruskal-Wallis; $\chi^{2}=16.35$; $\mathrm{p}<0.001$; same superscript letters indicate similarity between years). AST: aspartate transaminase

\begin{tabular}{|c|c|c|c|}
\hline Variable & 2007 & 2008 & 2009 \\
\hline Hematocrit & $0.52(0.08)$ & $0.47(0.07)$ & $0.54(0.07)$ \\
\hline Total protein $\left(\mathrm{g} \mathrm{l}^{-1}\right)$ & $46(4)$ & $47(6)$ & $47(4)$ \\
\hline $\operatorname{AST}\left(\mathrm{U} \mathrm{l}^{-1}\right)$ & $1080(277)$ & $1106(234)$ & $1222(389)$ \\
\hline Cholesterol $\left(\mathrm{mmol} \mathrm{l}^{-1}\right)$ & $10.4(1.9)$ & $11.1(2.3)$ & $11.8(2.1)$ \\
\hline Triglycerides $\left(\mathrm{mmol} \mathrm{l}^{-1}\right)$ & $2.9(1.1)$ & $2.5(1.4)$ & $2.2(0.6)$ \\
\hline Glucose $\left(\mathrm{mmoll}^{-1}\right)$ & $5.4(0.7)$ & $5.3(1.1)$ & $6.2(1.2)$ \\
\hline Sodium $\left(\mathrm{mmol} \mathrm{l}^{-1}\right)$ & $164(5)^{\mathrm{a}}$ & $171(7)^{b}$ & $161(7)^{\mathrm{a}}$ \\
\hline Potassium $\left(\mathrm{mmol} \mathrm{l}^{-1}\right)$ & $3.13(3.17)$ & $2.29(1.35)$ & $2.39(1.36)$ \\
\hline Chloride $\left(\mathrm{mmol}^{-1}\right)$ & $136(6)$ & $140(4)$ & $129(5)$ \\
\hline Calcium $\left(\mathrm{mmoll}^{-1}\right)$ & $3.00(0.24)$ & $2.98(0.32)$ & $2.80(0.26)$ \\
\hline Phosphorus (mmol l-1) & $3.22(0.57)$ & $3.36(0.35)$ & $3.61(0.57)$ \\
\hline Magnesium $\left(\mathrm{mmoll}^{-1}\right)$ & $1.37(0.14)$ & $1.35(0.17)$ & $1.27(0.15)$ \\
\hline
\end{tabular}

Table 4. Oncorhynchus tshawytscha. Rotated factor loadings and final communalities for factor analysis of blood chemistry data for summer-run Chinook salmon in the Puntledge River ( $n=58$ ). Loadings are multiplied by 100 and rounded to the nearest integer. Variables with factor loadings $\geq \pm 50$ are shown in bold. AST: aspartate transaminase

\begin{tabular}{|c|c|c|c|c|c|}
\hline \multirow[t]{2}{*}{ Plasma variable } & \multicolumn{4}{|c|}{ - Factor } & \multirow{2}{*}{$\begin{array}{c}\text { Final } \\
\text { communality } \\
\text { estimates }\end{array}$} \\
\hline & 1 & 2 & 3 & 4 & \\
\hline Eigenvalue & 4.00 & 2.38 & 1.28 & 1.13 & \\
\hline Calcium $\left(\mathrm{mmol} \mathrm{l}^{-1}\right)^{\mathrm{a}}$ & 89 & 22 & -10 & 3 & 0.842 \\
\hline Total protein $\left(\mathrm{g} \mathrm{l}^{-1}\right)$ & 84 & -12 & 18 & 15 & 0.783 \\
\hline Magnesium $\left(\mathrm{mmol} \mathrm{l}^{-1}\right)^{\mathrm{a}}$ & 72 & 47 & 11 & 19 & 0.788 \\
\hline Cholesterol $\left(\mathrm{mmol} \mathrm{l}^{-1}\right)$ & 68 & -23 & 14 & 9 & 0.545 \\
\hline Triglycerides $\left(\mathrm{mmol} \mathrm{l}^{-1}\right)^{\mathrm{a}}$ & 60 & 18 & -18 & -7 & 0.436 \\
\hline Phosphorus $\left(\mathrm{mmoll}^{-1}\right)^{\mathrm{a}}$ & 56 & 4 & 45 & 34 & 0.635 \\
\hline Chloride $\left(\mathrm{mmol} \mathrm{l}^{-1}\right)$ & 0 & 85 & -35 & -8 & 0.858 \\
\hline Sodium $\left(\mathrm{mmol} \mathrm{l}^{-1}\right)$ & 41 & 79 & -13 & 8 & 0.819 \\
\hline $\mathrm{AST}\left(\mathrm{U} \mathrm{l}^{-1}\right)$ & 30 & -62 & -19 & 29 & 0.600 \\
\hline Potassium $\left(\mathrm{mmol} \mathrm{l}^{-1}\right)^{\mathrm{a}}$ & -20 & -54 & -35 & -56 & 0.770 \\
\hline Glucose $\left(\mathrm{mmol} \mathrm{l}^{-1}\right)$ & 0 & -13 & 91 & -7 & 0.847 \\
\hline Hematocrit (\%) & 5 & -16 & -9 & 91 & 0.866 \\
\hline$\%$ variance explained & 33.4 & 19.8 & 10.7 & 9.4 & \\
\hline \multicolumn{6}{|c|}{${ }^{a}$ Variable has been $\log _{10}$ transformed } \\
\hline
\end{tabular}


ception of AST) and accounting for $19.8 \%$ of the variance. Rotated factor 3 was characterized by a high positive factor loading for glucose (Table 4), likely representing acute stress and explaining $10.7 \%$ of the variance. Rotated factor 4 accounted for $9.4 \%$ of the variance and had a high positive loading for hematocrit and a high negative loading for potassium (Table 4).

\section{Blood variables versus migratory behaviors and fates of SCS}

The number of days to ascend Nib Falls was positively correlated with endogenous energy stores and dietary minerals (Rotated factor $1 ; \mathrm{R}^{2}=0.25$; parameter estimate $=1.44, \mathrm{df}=1,26 ; F=8.49 ; \mathrm{p}=0.007$ ). This means that fish with higher positive values of calcium, total protein, magnesium, cholesterol, triglycerides, and phosphorus present in their blood at the time of sampling took longer to ascend Nib Falls than fish with high negative values of endogenous stores and dietary minerals (Fig. 2). No significant relationships were found between any other migratory behavior and rotated factors.

Fate was positively predicted by blood condition (Rotated factor $4 ; \mathrm{R}^{2}=0.11 ; \mathrm{n}=53 ; \chi^{2}=10.60 ; \mathrm{p}=$ 0.005), meaning that fish with higher hematocrit and lower potassium were more likely to be successful spawners than to be classified as prespawn mortality or fallback fish (Fig. 3). No significant relationships were found between any other classified migratory behaviors and rotated factors.

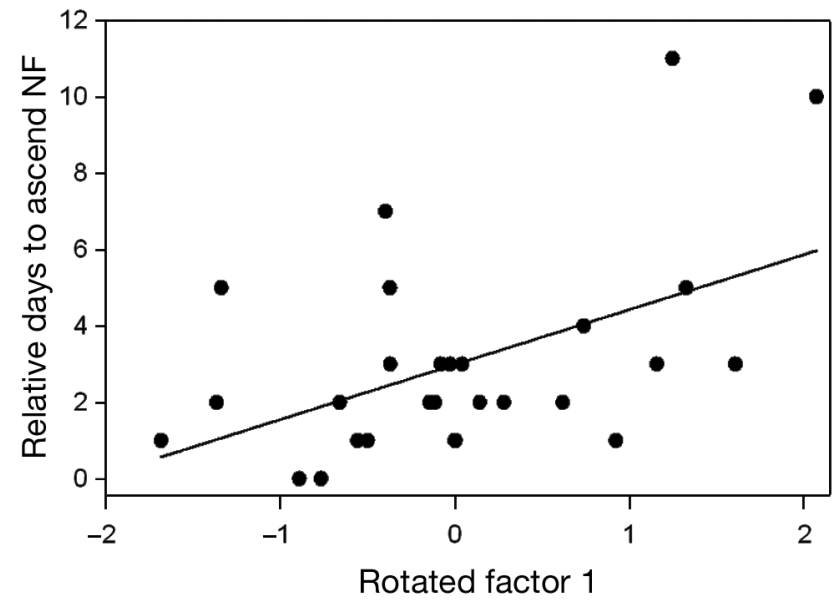

Fig. 2. Oncorhynchus tshawytscha. Linear regression of Rotated factor 1 (the only factor to elicit a statistical relationship between the factors and the migratory behaviors) and the relative number of days taken to ascend Nib Falls, NF (the number of days a fish took to ascend Nib Falls, after ascending Stotan Falls)

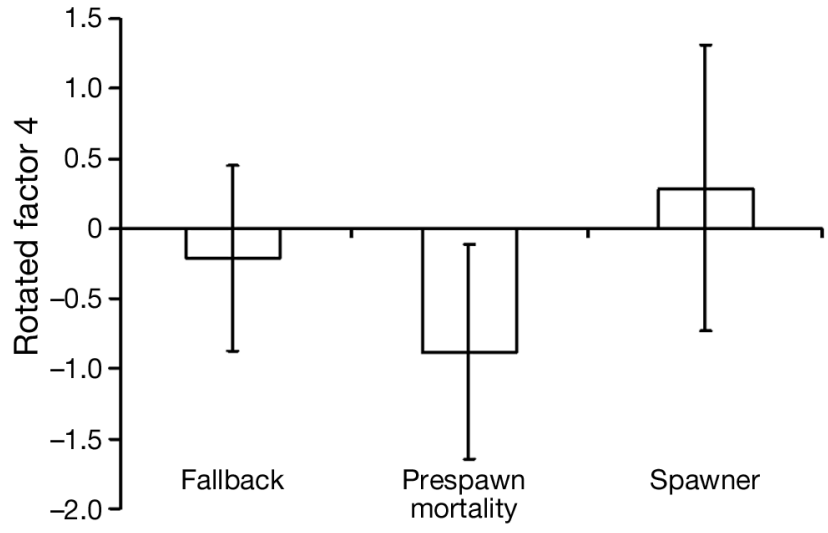

Fig. 3. Oncorhynchus tshawytscha. Mean values $( \pm \mathrm{SD})$ of positive loading of hematocrit and negative loading of potassium predicted by Rotated factor 4 (the only factor to elicit a statistical relationship) and the fates of fish classified as either fallback, prespawn mortality, or spawner

\section{DISCUSSION}

In an attempt to understand how a 'snapshot' of physiological condition may affect migratory behaviors and fate in a short regulated river, we compared blood variables to the migratory behaviors and fates of migrating Pacific salmon. This study is the first of its kind to assess SCS migratory behavior and blood variables, unlike previous physiological assessments that have focused primarily on late-run sockeye salmon. Also, our study focused on a small, steep, and hydropower-influenced river, whereas most previous studies have taken place on larger systems with comparatively low gradients (i.e. Fraser and Thompson Rivers).

\section{Blood variables versus migratory behaviors and fates of SCS}

We hypothesized that physiological status, energy use, and osmoregulatory preparedness would differentiate the variability observed in the migratory behaviors of fish at 'key barriers' to upstream movement. The length of time upstream-migrating adult SCS took to ascend Nib Falls once they arrived at the base of Nib Falls was characterized by positively loading indicators of endogenous energetic stores and other dietary minerals. High levels of energy reserves (i.e. lipids and proteins) in migrating salmon blood indicate that energy stores are being mobilized to fuel migration (Brett 1995). Cooke et al. (2006b) found that summerrun sockeye salmon Oncorhynchus nerka that failed to enter the Fraser River, British Columbia, had higher gross somatic energy; the authors suggested that the fish with lower gross somatic energy may have com- 
mitted to river entry and have already shifted energy reserves to fuel gonad maturation (Patterson et al. 2004). It may be that the Puntledge SCS that had higher endogenous energy stores and dietary minerals in their blood at the time of tagging were not as reproductively advanced as fish that ascended Nib Falls faster.

We also hypothesized that fish that were able to reach spawning grounds would be characterized by low levels of physiological stress, be in good nutritional condition, and be in a state of high osmoregulatory preparedness relative to fish that did not reach spawning grounds. Fate was weakly related to the hematocrit/potassium factor. Specifically, fish that were classified as spawners were more likely to have higher hematocrit and lower potassium, while fish that were classified to have died prior to spawning had lower hematocrit and higher potassium, possibly indicating stress and poor condition (Barton et al. 2002). However, because potassium levels were indicative of healthy fish, it is unclear how potassium contributed to fate.

It is important to note that for our significant relationships, the proportions of variability were not high (0.246 for Factor 1 and relative days to ascend Nib Falls; 0.109 for Factor 4 and fate). These low coefficients of determination mean that using these statistical relationships to assess future outcomes may lead to suspect conclusions. However, these significant relationships were found despite the small sample size. For example, Wagner \& Congleton (2004) used over 100 individuals in a PCA to assess blood chemistry correlates of condition, tissue damage, and stress in migrating juvenile Chinook salmon, whereas Hanson et al. (2007) used a PCA and found significant relationships between swimming performance and morphological correlates of 16 largemouth bass. The fact that we did find some significant relationships despite having a low sample size suggests that our relationships may be biologically relevant and that had we had a greater sample size, we may have seen more stronger and significant physiological correlates to migratory behavior and fate.

\section{Migratory behaviors and fate of SCS}

The speed at which the Puntledge River male SCS took to reach spawning grounds (i.e. ascend Nib Falls, $11.9 \mathrm{~km}$ in $\sim 22 \mathrm{~d}$ ) was less than in other systems. The Puntledge River SCS moved at a rate $\sim 2 \%$ slower than the rate of passive integrated transponder (PIT)-tagged SCS that moved between the Bonneville Dam and the Lower Granite Dam in the Columbia River system (Matter \& Sandford 2003). The fact that Puntledge River SCS moved at a slower rate may suggest that the river presents a number of challenges that delay or impede migration and/or that the physiology of these fish is compromised such that they are unable to migrate at higher speeds. Alternatively, it is possible that the Puntledge River stock has large variation in instream behaviors due to the long period from marine exit to spawning time and river shortness. Furthermore, stocking, which does occur on the river, may have imprinted some fish to migrate in an alternative pattern (Power \& McCleave 1980).

Fish spent considerable time at the Powerhouse Pool, Stotan Falls, and Nib Falls. These areas are likely 'stop-over' sites used by upstream migrating fish. Hydropower release sites and natural barriers often involve complex flow patterns, and it has been suggested that this leads to difficulty in locating flow cues (Hinch \& Rand 1998, Brown \& Geist 2002). In the Puntledge River, fish held at the Powerhouse Pool between 0 and $41 \mathrm{~d}$. Similarly, Scruton et al. (2007) found that upstream-migrating Atlantic salmon Salmo salar were attracted to a hydropower tailrace in a Newfoundland river for up to 12 d. Rivinoja et al. (2001) also reported that migrating Atlantic salmon were located near hydropower outlets in a northern Swedish river. The stop-overs at Stotan Falls and Nib Falls tended to be longer than those experienced by fish at other fishways at man-made barriers (e.g. dams) in other river systems (Gowans et al. 2003, Scruton et al. 2007, Pon et al. 2009a).

Twelve fish were classified as fallbacks, which could have been related to tagging methods and handling stress (Bernard et al. 1999). However, recent work has suggested that fallback is a part of typical movement behaviors in anadromous fish (Frank et al. 2009), and in the case of this study, fish that fell back were required to naturally re-ascend the hatchery fish ladder in order to resume their upstream migration. This happened for 2 fish, and both were able to reach historic spawning areas (note that these fish were classified as spawners and not fallbacks).

Sex differences have been shown to affect spawning migrations in Pacific salmon (Quinn 2005) and to influence physiological profiles (Brett 1995, Sandblom et al. 2009). In the present study, only male fish were sampled because the female population was captured and used to produce hatchery brood stock. Males typically reach spawning grounds earlier than females (McKinstry 1993); thus the observed rates may have been slower if females were sampled. Furthermore, females may have held at preferable sites longer to conserve energy and allow their gametes to mature, as females allocate more energy into sexual maturation (Brett 1995). Females also have different physiological profiles (Sandblom et al. 2009); female sockeye salmon were found to have higher levels of acute stress indicators (i.e. cortisol, 
glucose, and sodium) and reproductive hormones (i.e. 11-ketotestosterone, testosterone, 17 $\beta$-estradiol) when compared to males (Sandblom et al. 2009).

\section{Blood variables}

Pacific salmon cease feeding before entering fresh water and do not eat during the upstream migration (Groot \& Margolis 1991, Brett 1995). We found that Factor 1 from the factor analysis represented a gradient among individuals in endogenous energy stores and dietary minerals (e.g. calcium, total protein, magnesium, cholesterol, triglycerides, and phosphorus). These variables reflect fasting and starvation in fish (e.g. Robertson et al. 1961, Congleton \& Wagner 2006, Hanson \& Cooke 2009). In general, the range of endogenous stores we found represents typical values for adult salmon at this point in their migration. Specifically, total protein indicates the amount of albumin and globulin molecules present in the blood, and decreasing levels of total protein are found in starving fish. Our total protein values reflected previous findings (Robertson et al. 1961, Congleton \& Wagner 2006). Cholesterol is a lipid present in animal tissue and is also found to decrease in starving fish (Robertson et al. 1961, Congleton \& Wagner 2006). Plasma cholesterol was $~ 11.1 \mathrm{mmol} \mathrm{l}^{-1}$, and this value is within the range reported by Robertson et al. (1961) for fish that were between ocean and spawning habitats. Triglycerides are the major storage form of fat, and like total protein and cholesterol, concentrations decrease in starving fish (e.g. Congleton \& Wagner 2006, Hanson \& Cooke 2009) and fish undertaking spawning migrations (Ballantyne et al. 1996, Kiessling et al. 2004, Magnoni et al. 2006). The Puntledge River SCS mean triglyceride value was $\sim 2.5 \mathrm{mmol} \mathrm{l}^{-1}$, which is below what Magnoni et al. (2006) found in migrant sockeye salmon $\left(4.0 \mathrm{mmol} \mathrm{l}^{-1}\right)$.

Phosphorus and magnesium are abundant dietary ions. Magnesium is typically obtained from either the surrounding environment or dietary processes and is an essential cofactor in many enzymatic reactions. We found magnesium to range from 1.27 to $1.37 \mathrm{mmol} \mathrm{l}^{-1}$, which is below what Snodgrass \& Halver (1971) reported for adult Chinook salmon in fresh water (i.e. 1.81 to $2.51 \mathrm{mmol} \mathrm{l}^{-1}$ ). Phosphorus is mainly absorbed by fish via food sources and is an ion used for many metabolic and growth processes. We found yearly concentrations of phosphorus ions in the blood to range from 3.22 to $3.61 \mathrm{mmol} \mathrm{l}^{-1}$, which is higher than those reported for fasting adult largemouth bass (Hanson \& Cooke 2009). To our knowledge, no baseline values for phosphorus in adult Chinook salmon have been reported in the literature.
Average plasma calcium values ranged from 2.80 to $3.00 \mathrm{mmol} \mathrm{l}^{-1}$ which may indicate that the sampled fish are in a state of hypocalcemia, as previous work has found normal values to be above $5 \mathrm{mmol} \mathrm{l}^{-1}$ (Snodgrass \& Halver 1971). Low levels of calcium in Chinook salmon have been shown to reduce growth and result in poor feed conversion (Lall 2002). Sexual maturing Atlantic salmon utilize calcium for remodeling their body shape, so the hypocalcemia observed may impact the ability of the sampled Chinook salmon to form sexual characteristics (Kacem et al. 1998, 2000, Witten \& Hall 2003).

The osmoregulatory preparedness factor was composed of 4 variables. Sodium, chloride, and potassium represent a suite of ions that allowed us to investigate the effects of osmoregulatory preparedness. In general, our study fish had normal concentrations of osmoregulatory ions, but with a tendency to be more suited to $10 \%$ salinity water, suggesting that these fish were still undergoing physiological changes associated with the transition into fresh water (Clarke \& Hirano 1995, Hinch et al. 2006, Donaldson et al. 2010). In juvenile Chinook salmon, invasive blood sampling techniques can elevate AST and plasma potassium, and decrease plasma sodium and chloride when compared to the least invasive technique, caudal vessel puncture (Congleton \& LaVoie 2001). Overall, our fish were not undergoing osmoregulatory stress at the time of sampling.

The 2 remaining factors were a glucose factor and a hematological factor (Table 4). The glucose factor solely comprised glucose, which may indicate acute stress because plasma glucose is responsive to stressors (Wendelaar Bonga 1997) and is not likely to be influenced by feeding because the sampled fish were fasting (Navarro \& Gutiérrez 1995). Similar plasma glucose concentrations were found in healthy migrating Chinook salmon (D. A. Patterson et al. unpubl. data). The blood factor was comprised of hematocrit and potassium. Hematocrit is the packed cell volume of blood and was found to be $\sim 0.51$ (Table 3). Hematocrit is not a particularly sensitive stress indicator (Barton et al. 2002) and, like glucose, can change rapidly in response to handling and blood collection methods (Sandblom et al. 2009). As discussed earlier, plasma potassium was within the range of typical concentrations reported for Pacific salmon during the upriver portion of the spawning migration.

\section{CONCLUSIONS}

Our results indicate that although physiological and nutritional condition can influence adult migrating male SCS, we did not find a physiological profile that 
could explain a large portion of the extensive variation in migratory behavior observed. This result suggests that variation in physiological and nutritional condition among individual fish at the time near river entry is not an important influence on the migration behavior in this system. Our physiological profiles suggest that the Puntledge River SCS are in good condition with minimal physiological stress. Migratory behaviors were slower than in other larger systems, but fish were able to reach spawning grounds and presumably spawned. This study could serve as a baseline for assessing other populations and their physiological states and may be useful in identifying populations in need of conservation efforts. In addition, this study represents one of the first examples of using conservation physiology to understand problems associated with an imperiled population of river fish.

Acknowledgements. We thank the staff at the Puntledge River Fish Hatchery for logistical support and for fish capture, especially D. Miller, B. Munro, and L. Frisson; A. Colotelo, C. Dey, C. Hatry, M. Taylor, and S. Wilson for field assistance; and K. Hanson for help with the statistical analysis. J. Hill, V. Ives, T. Nettles, and J. Carter helped with the physiological analysis. M. Sheng and E. Wichman provided logistical support. Funding for this project was provided by BC Hydro's Water Use Planning, and the DFO Environmental Watch Program. C.T.H. and M.R.D. were each supported by an Alexander Graham Bell Canada Graduate Scholarship from NSERC. The research and procedures carried out in this publication were conducted in accordance with the Animal Care Committee at Carleton University (protocol no. B06-12), and fish were collected using a Fisheries and Oceans Canada Collection Permit.

\section{LITERATURE CITED}

Ballantyne JS, Mercure F, Gerrits MF, Van Der Kraak G and others (1996) Plasma nonesterified fatty acid profiles in male and female sockeye salmon, Oncorhynchus nerka, during the spawning migration. Can J Fish Aquat Sci 53: 1418-1426

Barton BA, Morgan JD, Vijayan MM (2002) Physiological and condition-related indicators of environmental stress in fish. In: Adams SM (ed) Biological indicators of aquatic ecosystem stress. American Fisheries Society, Bethesda, MD, p 111-148

Bernard DR, Hasbrouck JJ, Fleischman SJ (1999) Handlinginduced delay and downstream movement of adult chinook salmon in rivers. Fish Res 44:37-46

Brett JR (1995) Energetics. In: Groot C, Margolis L, Clarke WC (eds) Physiological ecology of Pacific salmon. University of British Columbia Press, Vancouver, BC, p 1-68

Brown RS, Geist DR (2002) Determination of swimming speeds and energetic demands of upriver migrating fall chinook salmon (Oncorhynchus tshawytscha) in the Klickitat River, Washington. Project 22063. Contract 42663A. Pacific Northwest Laboratory, Bonneville Power Administration, Richland, WA. Available at https:// psces.bpa.gov/ release/documents/documentviewer.aspx?doc=00000652-9

> Caudill CC, Daigle WR, Keefer ML, Boggs CT and others (2007) Slow dam passage in adult Columbia River sal- monids associated with unsuccessful migration: delayed negative effects of passage obstacles or condition-dependent mortality? Can J Fish Aquat Sci 64:979-995

Clarke WC, Hirano T (1995) Osmoregulation. In: Groot C, Margolis L, Clarke WC (eds) Physiological ecology of Pacific salmon. University of British Columbia Press, Vancouver, BC, p 317-378

Congleton JL, LaVoie WJ (2001) Comparison of blood chemistry values for samples collected from juvenile Chinook salmon by three methods. J Aquat Anim Health 13:168-172

Congleton JL, Wagner T (2006) Blood-chemistry indicators of nutritional status in juvenile salmonids. J Fish Biol 69: 473-490

Cooke SJ, O'Connor CM (2010) Making conservation physiology relevant to policy makers and conservation practitioners. Conserv Lett 3:159-166

Cooke SJ, Hinch SG, Wikelski M, Wolcott TG, Butler PJ (2004) Biotelemetry: a mechanistic approach to ecology. Trends Ecol Evol 19:334-343

Cooke SJ, Crossin GT, Patterson DA, English KK and others (2005) Coupling non-invasive physiological assessments with telemetry to understand inter-individual variation in behaviour and survivorship of sockeye salmon: development and validation of a technique. J Fish Biol 67:1342-1358

Cooke SJ, Hinch SG, Crossin GT, Patterson DA and others (2006a) Physiology of individual late-run Fraser River sockeye salmon (Oncorhynchus nerka) sampled in the ocean correlates with fate during spawning migration. Can J Fish Aquat Sci 63:1469-1480

Cooke SJ, Hinch SG, Crossin GT, Patterson DA and others (2006b) Mechanistic basis of individual mortality in Pacific salmon during spawning migrations. Ecology 87:15751586

Cooke SJ, Hinch SG, Crossin GT, Patterson DA and others (2008a) Physiological correlates of coastal arrival and river entry timing in late summer Fraser River sockeye salmon (Oncorhynchus nerka). Behav Ecol 19:747-758

Cooke SJ, Hinch SG, Farrell AP, Patterson DA and others (2008b) Developing a mechanistic understanding of fish migrations by linking telemetry with physiology, behavior, genomics and experimental biology: an interdisciplinary case study on adult Fraser River sockeye salmon. Fisheries 33:321-338

Crossin GT, Hinch SG, Welch DW, Cooke SJ and others (2009a) Physiological profiles of sockeye salmon in the Northeastern Pacific Ocean and the effects of exogenous $\mathrm{GnRH}$ and testosterone on rates of homeward migration. Mar Freshw Behav Physiol 42:89-108

Crossin GT, Hinch SG, Cooke SJ, Cooperman MS and others (2009b) Mechanisms influencing the timing and success of reproductive migration in a capital breeding, semelparous fish species: the sockeye salmon. Physiol Biochem Zool 82: $635-652$

> Donaldson MR, Hinch SG, Patterson DA, Farrell AP and others (2010) Physiological condition differentially affects the behaviour and survival of two populations of sockeye salmon during their freshwater spawning migration. Physiol Biochem Zool 83:446-458

Enders EC, Scruton DA, Clarke KD (2009) The 'natural flow paradigm' and Atlantic salmon-moving from concept to practice. River Res Appl 25:2-15

Frank HJ, Mather ME, Smith JM, Muth RM, Finn JT, McCormick SD (2009) What is 'fallback'?: metrics needed to assess telemetry tag effects on anadromous fish behavior. Hydrobiologia 635:237-249

> Gowans ARD, Armstrong JD, Priede IG, Mckelvey S (2003) Movements of Atlantic salmon migrating upstream 
through a fish-pass complex in Scotland. Ecol Freshw Fish 12:177-189

Groot C, Margolis L (eds) (1991) Pacific salmon life histories. University of British Columbia Press, Vancouver, BC

$>$ Hanson KC, Cooke SJ (2009) Nutritional condition and physiology of paternal care in two congeneric species of black bass (Micropterus spp.) relative to stage of summer development. J Comp Physiol B Biochem Syst Environ Physiol 179:253-266

Hanson KC, Hasler CT, Suski CD, Cooke SJ (2007) Morphological correlates of swimming activity in wild largemouth bass (Micropterus salmoides) in their natural environment. Comp Biochem Physiol A Mol Integr Physiol 148: 913-920

Hasler CT, Pon LB, Roscoe DW, Mossop B, Patterson DA, Hinch SG, Cooke SJ (2009) Expanding the 'toolbox' for studying the biological responses of individual fish to hydropower infrastructure and operating strategies. Environ Rev 17:179-197

Hinch SG, Rand PS (1998) Swim speeds and energy use of upriver-migrating sockeye salmon (Oncorhynchus nerka): role of local environment and fish characteristics. Can J Fish Aquat Sci 55:1821-1831

Hinch SG, Cooke SJ, Healey MC, Farrell AP (2006) Behavioural physiology of fish migrations: salmon as a model approach. In: Sloman K, Balshine S, Wilson R (eds) Fish physiology, Vol 24: behaviour and physiology of fish. Elsevier Press, New York, NY, p 239-295

Hirst SM (1991) Impacts of the operation of existing hydroelectric developments of fishery resources in British Columbia. Canadian Manuscript Report of Fisheries and Aquatic Sciences 2093. Habitat Management Division Pacific Region, Department of Fisheries and Oceans, Vancouver, BC

Kacem A, Meunier F, Bagliniere J (1998) A quantitative study of morphological and histological changes in the skeleton of Salmo salar during its anadromous migration. J Fish Biol 53:1096-1109

> Kacem A, Gustafsson S, Meunier FJ (2000) Demineralization of the vertebral skeleton in Atlantic salmon Salmo salar L. during spawning migration. Comp Biochem Physiol A Mol Integr Physiol 125:479-484

Keefer ML, Peery CA, Bjornn TC, Jepson MA, Stuehrenberg LC (2004) Hydrosystem, dam, and reservoir passage rates of adult Chinook salmon and steelhead in the Columbia and Snake Rivers. Trans Am Fish Soc 133:1413-1439

Keefer ML, Peery CA, Heinrich MJ (2008) Temperaturemediated en route migration mortality and travel rates of endangered Snake River sockeye salmon. Ecol Freshw Fish 17:136-145

Kiessling A, Lindahl-Kiessling K, Kiessling KH (2004) Energy utilization and metabolism in spawning migrating Early Stuart sockeye salmon (Oncorhynchus nerka): the migratory paradox. Can J Fish Aquat Sci 61:452-465

Lall SP (2002) The minerals. In: Halver JE, Hardy RW (eds) Fish nutrition, 3rd edn. Academic Press, New York, NY, p 260-309

Magnoni LJ, Patterson DA, Farrell AP, Weber JM (2006) Effects of long-distance migration on circulating lipids of sockeye salmon (Oncorhynchus nerka). Can J Fish Aquat Sci 63:1822-1829

Mathes MT, Hinch SG, Cooke SJ, Crossin GT, Patterson DA, Lotto AG, Farrell AP (2010) Effect of water temperature, timing, physiological condition and lake thermal refugia on migrating adult Weaver Creek sockeye salmon (Oncorhynchus nerka). Can J Fish Aquat Sci 67: $70-84$
Matter AL, Sandford BP (2003) A comparison of migration rates of radio- and PIT-tagged adult Snake River Chinook salmon through the Columbia River hydropower system. N Am J Fish Manag 23:967-973

> McCormick SD (1993) Methods for the nonlethal gill biopsy and measurements of $\mathrm{Na}^{+}, \mathrm{K}^{+}$-ATPase activity. Can J Fish Aquat Sci 50:656-658

McKinstry CA (1993) Forecasting migratory timing and abundance of pink salmon (Oncorhynchus gorbuscha). MS thesis, University of Washington, Seattle, WA

Miller KM, Shaorong L, Kaukinen KH, Ginther N and others (2011) Genomic signatures predict migration and spawning failure in wild Canadian salmon. Science 331:214-217

> Murchie KJ, Smokorowski KE (2004) Relative activity of brook trout and walleyes in response to flow in a regulated river. N Am J Fish Manag 24:1050-1057

Navarro I, Gutiérrez J (1995) Fasting and starvation. In: Hochachka PW, Mommsen TP (eds) Biochemistry and molecular biology of fishes. Vol 4. Elsevier Science, New York, NY, p 393-434

Patterson DA, Macdonald JS, Hinch SG, Healey MC, Farrell AP (2004) The effect of exercise and captivity on energy partitioning, reproductive maturation and fertilization success in adult sockeye salmon. J Fish Biol 64:1039-1059

Poff NL, Allan JD, Bain MB, Karr JR and others (1997) The natural flow regime: a paradigm for river conservation and restoration. Bioscience 47:769-784

Pon LB, Hinch SG, Cooke SJ, Patterson DA, Farrell AP (2009a) Physiological, energetic and behavioural correlates of successful fishway passage of adult sockeye salmon Oncorhynchus nerka in the Seton River, British Columbia. J Fish Biol 74:1323-1336

Pon LB, Hinch SG, Cooke SJ, Patterson DA, Farrell AP (2009b) A comparison of the physiological condition, and fishway passage time and success of migrant adult sockeye salmon at Seton River dam, British Columbia, under three operational water discharge rates. N Am J Fish Manag 29:1195-1205

> Power JH, McCleave JD (1980) Riverine movements of hatchery-reared Atlantic salmon (Salmo salar) upon return as adults. Environ Biol Fishes 5:3-13

Quinn TP (2005) The behaviour and ecology of Pacific salmon and trout. American Fisheries Society, Bethesda, MD

Rivinoja P, McKinnell S, Lundqvist H (2001) Hindrances to upstream migration of Atlantic salmon (Salmo salar) in a northern Swedish river caused by a hydroelectric powerstation. Regul Rivers Res Manag 17:101-115

Robertson OH, Krupp MA, Favour CB, Hane S, Thomas SF (1961) Physiological changes occurring in the blood of the Pacific salmon (Oncorhynchus tshawytscha) accompanying sexual maturation and spawning. Endocrinology 68:733-746

Roscoe DW, Hinch SJ, Cooke SJ, Patterson DA (2011) Fishway passage and post-passage mortality of up-river migrating sockeye salmon in the Seton River, British Columbia. Riv Res Appl (in press)

> Sandblom E, Clark TD, Hinch SG, Farrell AP (2009) Sex-specific differences in cardiac control and hematology of sockeye salmon (Oncorhynchus nerka) approaching their spawning grounds. Am J Physiol Regul Integr Comp Physiol 297:R1136-R1143

Scruton DA, Booth RK, Pennell CJ, Cubitt F, McKinley RS, Clarke KD (2007) Conventional and EMG telemetry studies of upstream migration and tailrace attraction of adult Atlantic salmon at a hydroelectric installation on the Exploits River, Newfoundland, Canada. Hydrobiologia 582:67-79 
Snodgrass PJ, Halver JE (1971) Potassium, sodium, magnesium and calcium contents of chinook salmon tissues during various stages of the life cycle. Comp Biochem Physiol A Physiol 38:99-119

Taylor JA, Guimond E (2004) Puntledge River summer run Chinook radio telemetry study 2003. Prepared for Fisheries and Oceans Canada, Nanaimo, BC

Thorstad EB, Økland F, Kroglund F, Jespen N (2003) Upstream migration of Atlantic salmon at a power station on the River Nidelva, southern Norway. Fish Manag Ecol 10:139-146

Tiffan KF, Haskell CA, Kock TJ (2010) Quantifying the behavioural response of spawning chum salmon to elevated discharges from Bonneville Dam, Columbia River, USA. River Res Appl 26:87-101

Ueda H, Yamauchi K (1995) Biochemistry of fish migration. In: Hochachka PW, Mommsen TP (eds) Environmental

Editorial responsibility: Rory Wilson,

Swansea, UK and ecological biochemistry. Elsevier, New York, NY, p 265-279

Wagner T, Congleton JL (2004) Blood chemistry correlates of nutritional condition, tissue damage, and stress in migrating juvenile chinook salmon (Oncorhynchus tshawytscha). Can J Fish Aquat Sci 61:1066-1074

Wendelaar Bonga SE (1997) The stress response in fish. Physiol Rev 77:591-625

Witten PE, Hall BK (2003) Seasonal changes in the lower jaw skeleton in male Atlantic salmon (Salmo salar L.): remodeling and regression of the kype after spawning. J Anat 203:435-450

> Young JL, Hinch SG, Cooke SJ, Crossin GT and others (2006) Physiology and energetic correlates of en route mortality for abnormally early migrating adult sockeye salmon (Oncorhynchus nerka) in the Thompson River, British Columbia. Can J Fish Aquat Sci 63:1067-1077

Submitted: September 30, 2010; Accepted: March 9, 2011 Proofs received from author(s): May 13, 2011 